\title{
An investigation of Taiwanese arts students' English learning attitudes
}

\author{
Tseng, Min-Chen $\bowtie$ \\ General Education Center, National Taiwan University of Arts, Taiwan (janetseng@ntua.edu.tw)
}

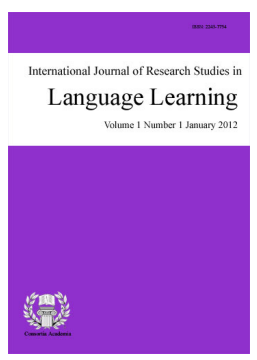

ISSN: 2243-7754 Online ISSN: 2243-7762

OPEN ACCESS

\begin{abstract}
In Taiwan, arts students spend most of their time developing their professions, such as musical instruments, acting, dancing, and painting. With the increasing importance of English in this global village and every Taiwanese university has set English capability as one of the graduation requirements, arts students must be aware that they need to acquire a good facility with English. This study investigated the English learning attitudes of Taiwanese university students majoring in the arts such as Fine Arts, Motion Pictures, Applied Drama \& Theatre, Music, and Dance. A questionnaire consisted of two parts: part one focused on basic information and relevant English activities and part two covered English learning attitudes. The results show students spent about 10.40 hours per week doing English related activities and they realized the importance of learning English with a mean score of 93.92. They were also aware of the fact that English would help them greatly in the future, and good English would be useful for their careers after graduation. However, they did not like to raise their hands and asked teacher questions in the classes. They did not feel confident to speak English in front of their teachers and classmates.
\end{abstract}

Keywords: arts students; language attitudes; English learning; Taiwanese students 


\section{An investigation of Taiwanese arts students' English learning attitudes}

\section{Introduction}

Though attitudes toward learning English have been extensively studied in numerous countries (Yoshikawa, 2000; Tsuda \& Shuib, 2003; Al-Tamimi, 2009; Bidin, Jusoff, Aziz, Salleh, \& Tajudin, 2009; Sayadian \& Lashkarian, 2010; Abidin, Pour-Mohammadi, \& Alzwari, 2012; Zafarghandi \& Jodai, 2012; Noursi, 2013), few studies have focused on arts students, which is a group of students with unique characteristics. In Taiwan, arts students usually attend talent classes such as music and fine arts starting in junior or senior high school. Whereas other students study hard for the Joint College Entrance Exam, arts students spend most of their time practicing their skills, such as musical instruments, acting, dancing, and painting. Academic subjects are often neglected, and English in particular because it does not play a critical role in the arts university entrance exams. Instead, arts students are admitted to a university according to their artworks, performances, or prizes from art competitions. With the promotion of internationalization, however, arts students are now more frequently required to or invited to attend international performances, exhibitions, or conferences. Thus a good command of English will definitely help them gain benefits in their academic, professional, and personal domains. English becomes especially instrumental for these students when they enter the international job market, and it has become a necessary tool for advancement.

In addition, because every university in Taiwan sets English benchmarks for students' expected English proficiency levels, arts students must face the fact that they can no longer avoid English-language learning. It is crucial to bear in mind that art-related academic departments are distinguished from other comprehensive universities because of the extremely practically-oriented nature of the subjects and training they offer. Therefore, it is necessary to examine arts students' attitudes toward learning English and to investigate current English learning activities for these arts students. The results would make contribution to the literature of how to teach English to arts students. Therefore, the current study addressed the following research questions:

1. What was the amount of time that students spent on relevant English activities and what were their prospects of English proficiency level?

2. What were the arts students' attitudes toward English?

3. Was the time students spent on English activities correlated with their attitudes?

\section{Literature Review}

Attitudes toward a language are developed from peoples' views about those who speak the languages and the contexts and functions with which they are associated (Holmes, 1998). Language learners have different attitudes toward the target language, target language speakers, the target-language culture, the social value of language culture (Ellis, 1994). He also further explains that "The attitudes are likely to reflect the particular social settings in which learners find themselves. Learner attitudes have an impact on the level of L2 proficiency achieved by individual learners and are themselves influenced by this success" (Ellis, 1994, p. 198). The most important attitude is group-specific, that is, the attitude learners have toward the members of the cultural group whose language they are learning. Attitude has cognitive, affective, and cognitive components, such as beliefs, emotional reactions, and behavioral tendencies. Attitude consists of an underlying psychological predisposition to act or evaluate behavior in a certain way. In addition, attitudes are linked to people's values and beliefs, and they promote or discourage choices made in all realms of activity, whether academic or informal (Gardner, 1985).

Why is attitude important in learning English? A relationship between attitudes and achievement has been 
An investigation of Taiwanese arts students' English learning attitudes

shown to exist. Schibeci and Riley (1986) report that attitudes influence students' achievement, rather than achievement influencing attitudes. Students with positive attitudes tend to have higher scores on achievement measures (Oliver \& Simpson, 1988; Weinburgh, 1994) and tend to experience success. Weinburgh (2000) points out that attitudes are believed to influence behaviors, such as electing courses, selecting and reading books, and learning behaviors in the classroom. Also, Nunan (1991) studies successful language learners and states that the students' determination to apply their developing language outside the classroom is a critical element for learners in terms of their second language development. Several studies focused on the time EFL learners spent with learning English activities.

Pickard (1996) studied a group of twenty German-speaking first-year undergraduate students. They all had studied English as a first foreign language. It was found that the students liked to do reading and listening activities, rather than productive activities such as speaking and writing. Yap (1998) studied eighteen Anglo-Chinese students of Arts stream in Hong Kong. The results show that students preferred activities involving language processing skills more than those using production skills. They preferred to read newspapers and watch English language television programs. They did not have a lot of opportunities for speaking and writing. Pill (2001) also studied adult learners of English in Hong Kong. He found that the context of Hong Kong was seemingly rich in opportunities to use and practice English, but the adult learners rarely had interaction with native speakers. In this study, the time engaging in English-related activities for the arts students was investigated and it was determined to see if it was related with positive or negative learning attitudes.

Baker (1988) discusses the main characteristics of attitudes: (1) attitudes are cognitive and affective; (2) attitudes are dimensional rather than bipolar, and they vary in degree of favorability/unfavorability; (3) attitudes predispose a person to act in a certain way, but the relationship between attitudes and action is not a strong one; (4) attitudes are learned, not inherited or genetically endowed; (5) attitudes tend to persist, though they can be modified by experience. The features and issue of attitudes triggers much interest for numerous scholars. Chen, Chuo, and Chuo (2003) investigated Taiwanese students' attitudes toward English instruction. They found that their students were confident in their current college English education, but that they expressed a lack of confidence in their pre-college English education. This was attributed to teaching methods, materials, and exams. Additionally, the students thought their university English programs, which emphasized vocabulary, dialog, and play, met their expectations. Suad and Lamees (2009) investigated Kuwaiti students' attitudes and preferences toward learning English, finding that the majority of students realized the importance of learning English. The students' high school English learning experiences influenced the way they learned English, and most students did not consider that they found the four English skills to be difficult. Students preferred to learn English through discussion, multimedia, and computers, and they liked teachers who could train them more in English fluency.

Abdel-Rahman (2009) studied the Jordanian students' attitudes toward learning English as a foreign language. The results show that $64 \%$ of students formed positive attitudes toward English. Half of the students responded that their parents played a critical role in their decision to choose English as a major. The majority of the students (64\%) thought English would give them a chance to have a better-paying job, and $46 \%$ of the students chose English as a major because it would give them the opportunity to become familiar with foreign culture. Gan (2009) examined students' attitudes in Mainland China and Hong Kong. That study found that it was falsely assumed that Asian students were prone to rote learning and that they were passive and teacher-dependent. Instead, the study showed that it was the institutional context and social environment that tended to decide students attitudes toward learning English. In recent years, Sung and Tsai (2014) investigated motivational factors and learner variables. The participants were 130 first-year foreign language learners in the US. The results show seven motivational factors: positive learning attitude/experience and intended efforts, interest in culture, travel, and people, interest in contemporary cultural media, milieu, instrumentality, language requirement, and religion. Among the factors, major and religion were significant predictors on motivation. These studies were mainly focusing on the attitudes that EFL students carried, but none of them were discussing the arts students. Therefore, the current study aimed at delving into arts students' attitudes toward learning English and examined whether or not there was a relationship between the time spent with studying English and 
Tseng, M.-C.

students' attitudes.

\section{Methodology}

\subsection{Participants}

A total of 83 students majoring in art-related fields participated in this study. Among the students, there were 64 females and 19 males. The average age was 18.87 years. Sixteen participants came from the Department of Radio and Television, 15 of whom majored in Motion Pictures. Another 15 students majored in Graphic Communication Arts. Ten students studied in Visual Communication Design. Eight students majored in Multimedia and Animation Art, and 8 students majored in Drama. The other students were from Craft Design, Fine Arts, Chinese Music, and Dance. Their language proficiency level ranged from Intermediate to High Intermediate on the basis of the General English Proficiency Test (GEPT). The GEPT was developed by the Language Training and Testing Center at National Taiwan University. It is divided into five levels: Elementary, Intermediate, High-Intermediate, Advanced, and Superior. It is commonly recognized by various government institutions, companies, and schools in Taiwan.

\subsection{Materials}

The questionnaire was composed of two main parts: basic information and relevant English activities, and students' language learning attitudes (See Appendix I):

Part I Basic information and relevant English activities: Thirteen questions were listed in this section, including gender, age, grade, foreign experiences, and the time they spend using English in various activities, including reading textbooks, watching movies or television programs, browsing Web sites, listening to radio programs, and completing English proficiency tests. The purpose of this section was to discover how many hours per week students spent on English-related tasks and their current English proficiency levels.

Part II English Learning Attitude: This section consisted of 15 questions to investigate students' attitudes toward learning English. To measure individual attitudes, Gardner and Lambert (1972) designed a questionnaire to be given to persons involved in second language study or bilingual situations. The respondents were asked to mark each question on a Likert-type scale of 7 points. Figure 1 shows an example of the scale students used to answer the questions. The questions included students' confidence in speaking English, the importance of learning, whether or not they think English will help them for their future, and others. The reliability of each question was determined using Cronbach's alpha, which was .879, indicating high reliability.

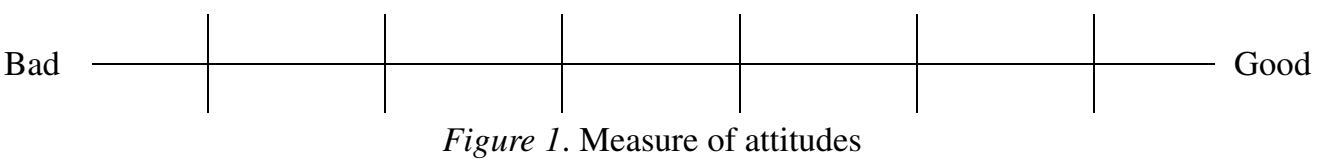

\subsection{Procedure}

At the beginning of the English class, it was explained to the participants that a study was to be conducted to investigate their attitudes toward learning English and the number of hours they spent each week on English learning activities. The importance of their participation in the study was explained to them. They were guaranteed that their performance in these tests would not influence their grades, and that they were free to drop the study at any time. After the completion of the questionnaires, the data extracted were analyzed using SPSS (Statistical Package for the Social Sciences) 17.0 for Windows and Microsoft XP and Excel. One sample t-test and a correlation test were used in statistical processing. 


\section{Results}

\subsection{Part I Analysis of basic information and relevant English activities}

A total of 83 students completed and returned the questionnaires, and Table 1 demonstrates the results. The participants spent approximately 10.40 hours completing English related activities every week. That time included 0.87 hours per week reading books written in English. One student spent 20 hours reading English novels and books each week. The students spent an average of 4.87 hours watching English television programs and movies (the maximum number of hours was 28). Most of participants majored in Radio \& Television, Motion Pictures, and Drama. Therefore, they spent considerable time watching English television programs and movies. Additionally, the participants used about 1.98 hours browsing English Web sites. Sometimes they were researching information for schoolwork, and they also often wanted to look for the most up-to-date art information. Two students each spent 14 hours surfing English Web sites every week. Participants spent about 1.16 hours per week listening to English radio programs. Three students, who majored in Radio and Television, listened to English radio programs for more than 9 hours a week. Because the Internet is an imperative tool to maintain their friendships, students chatted online with friends and classmates in English for approximately 0.91 hours each week. They did not use only the English language in their conversations, but mixed Mandarin and English in their dialogues. The time that they spoke in English was 0.59 hours.

\section{Table 1}

Results of Basic Information and Relevant English Activities for Arts Students

\begin{tabular}{|c|c|c|c|c|}
\hline Items & M & SD & $\begin{array}{c}\text { Minimum } \\
\text { hours }\end{array}$ & $\begin{array}{c}\text { Maximum } \\
\text { hours }\end{array}$ \\
\hline Total hours in English activities & 10.40 & 10.41 & 0 & 59 \\
\hline Books written in English & .87 & 2.57 & 0 & 20 \\
\hline English TV programs and movies & 4.87 & 5.16 & 0 & 28 \\
\hline English Web sites & 1.98 & 2.87 & 0 & 14 \\
\hline English radio programs & 1.16 & 2.10 & 0 & 10 \\
\hline Online Chat in English & .92 & 2.13 & 0 & 14 \\
\hline English Conversation & .59 & 1.07 & 0 & 5 \\
\hline
\end{tabular}

These numbers may mean little without a comparison with other data. Therefore, this study compares this data with the first-year and fifth-year medical students from a previous study (Tseng, 2009). See Table 2. The first-year medical students spent approximately 6.77 hours in English-related activities every week. This included reading books (3.81 hours), watching English television programs and movies (1.36 hours), browsing Web sites ( 0.65 hours), listening to English radio program (0.28 hours), chatting in English via MSN or Yahoo messengers (0.12 hours), and conversing in English (0.54 hours). Fifth-year students spent 9.92 hours each week in English-related activities. Those activities consisted of reading books (3.02 hours), watching English television programs and movies (2.57 hours), browsing Web sites (3.15 hours), listening to English radio programs (0.73 hours), online chatting in English (0.21 hours), and participating in English-language conversations (0.23 hours). Between the first-year and fifth-year students, there was a significant difference in watching English television programs and movies and viewing Web sites.

Comparing Table 1 with Table 2, it can be seen that the arts students spent more time in English-related activities than medical students. Overall, medical students used more time to read books written in English, perhaps because most of their textbooks were English versions. The arts students, however, usually used Chinese textbooks, and they spent more time watching English television programs and movies than first-year medical students, but less than fifth-year medical students. The arts students listened to English radio programs for more time than the medical students. Most arts participants, 31 out of 83, were majoring in Motion Pictures and Radio and Television, which explains why they spent more time on these activities than the medical students. The arts students browsed more English Web sites than the first-year medical students, and they chatted in English via the 
Tseng, M.-C.

Internet less than medical students.

Table 2

Results of Basic Information and Relevant English Activities for Medical Students

\begin{tabular}{|c|c|c|c|c|}
\hline Items & & $\mathrm{M}$ & SD & P-value \\
\hline \multirow{2}{*}{ Total hours in English activities } & First-year & 6.77 & 4.05 & \multirow{2}{*}{.07} \\
\hline & Fifth-year & 9.92 & 11.01 & \\
\hline \multirow{2}{*}{ Books written in English } & First-year & 3.81 & 3.41 & \multirow{2}{*}{.27} \\
\hline & Fifth-year & 3.02 & 3.53 & \\
\hline \multirow{2}{*}{ English TV programs and movies } & First-year & 1.36 & 1.85 & \multirow{2}{*}{$.03 *$} \\
\hline & Fifth-year & 2.57 & 3.26 & \\
\hline \multirow{2}{*}{ English Web sites } & First-year & .65 & .94 & \multirow{2}{*}{$.000 * * *$} \\
\hline & Fifth-year & 3.15 & 3.76 & \\
\hline \multirow{2}{*}{ English radio programs } & First-year & .27 & .71 & \multirow{2}{*}{.13} \\
\hline & Fifth-year & .73 & 1.88 & \\
\hline \multirow{2}{*}{ Online Chat in English } & First-year & .11 & .32 & \multirow{2}{*}{.36} \\
\hline & Fifth-year & .21 & .62 & \\
\hline \multirow{2}{*}{ English conversation } & First-year & .54 & .81 & \multirow{2}{*}{.07} \\
\hline & Fifth-year & .23 & .86 & \\
\hline
\end{tabular}

Note. $* p<.05 * * * p<.005$

\subsection{Part II English Learning Attitudes}

Since most arts students focus on practicing their professions, what were their attitudes toward English? The results were shown in Table 3. The total mean score for the fifteen questions was $72.67($ S.D. $=11.21)$. Among all the questions, the highest score was for Q3, which was about the importance of learning English. The mean score was 93.92. This means that the students know it is imperative to learn English well. The second highest score was for Q4, in which students reported that they realized that English would help them a lot in the future. The third highest score was for Q9, which showed that students thought English would be useful for their future after graduation. These three questions show that students genuinely knew English was essential and helpful both at school and at work.

\section{Table 3}

English Learning Attitude

\begin{tabular}{lcc}
\hline \multicolumn{1}{c}{ Items } & M & SD \\
\hline 1. I feel confident to speak in English. & 54.88 & 23.27 \\
2. I feel so happy to attend English classes. & 63.43 & 19.99 \\
3. I think it is important to learn English well. & 93.92 & 7.45 \\
4. I think English will help me a lot for my future. & 92.53 & 8.70 \\
5. I believe I have the ability to learn English well.. & 78.22 & 16.78 \\
\hline 6. I can absorb foreign culture in the English class. & 73.00 & 18.71 \\
7. I can understand most of the content of English textbook. & 81.52 & 15.04 \\
8. If I do not understand anything, I will ask teachers. & 59.05 & 20.39 \\
9. After graduation, English will be useful in a lot of places. & 85.54 & 15.37 \\
10. I like to learn anything about English. & 73.41 & 20.23 \\
\hline 11. I hope I can take more English classes. & 64.51 & 21.19 \\
12. I believe if I study hard, I can learn English well. & 80.88 & 18.36 \\
13. I am positive in learning English. & 59.80 & 23.31 \\
14. I would like to spend more time studying English. & 73.65 \\
15. If I do not know anything in the class, I will immediately raise my hand and ask teacher. & 54.39 & 19.67 \\
\hline
\end{tabular}

On the contrary, the lowest score was for Q15. Students did not raise their hands and ask the teacher questions if they did not know something in the class, which is a typical situation in Taiwanese English classes. Students felt embarrassed to ask the teacher questions in the class or during the lectures. They were afraid of asking stupid questions or felt that when they asked questions, everybody in the class would look at that them. 
Since they did not like to be the focus of the class, they usually came to ask the teacher questions during the break or after classes. The second lowest score was for Q1, indicating that the students did not feel confident in speaking English. This conformed to the observation above that students wish to have more conversation classes. The third lowest score was for Q8, indicating that students did not ask the teacher questions, preferring to ask their classmates. The students tended to maintain an emotional distance from their teachers because of the traditional Chinese notion that teachers should be highly respected.

To correlate the time spent on relevant English activities with students' attitudes, a positive correlation appeared $(r=0.451)$, and the correlation is significant at the 0.01 level (2-tailed).

\section{Discussions}

In response to research question 1, it is vital to invest considerable time to learn English well, and the arts students spent a total of 10.4 hours per week in relevant English tasks. Among all the English activities, students spent 4.87 hours with watching English television programs and movies (this was because 19\% of the student participants majored in Television \& Radio, Motion Pictures, and Drama). It was similar to Pickard and Yap' studies that EFL learners tend to do activities involving receptive skills such as reading and listening. Additionally, because of the convenience of the Internet, students could watch television programs and movies on their computers. Some students watched the programs for entertainment, but some students watched it for their school projects or assignments. As a matter of fact, of the six types of English activities, five could be conducted on the Internet. Students could browse different Web sites, listen to online radio programs, and chat or use Facebook with their friends. These results are similar to Suad and Lamees's (2009) study, which found that the Kuwait students were aware of the importance of learning English and they liked to learn English through multimedia and computers. On the other hand, students spent only 0.87 hours reading books. Because there was no pressure for the students to study English as they had done when they were studying at high schools, the university students seldom studied English from books or textbooks.

The answers to research question 2; English is paramount for students of different majors. No students could say they do not need to use English in their present student life or future career. Therefore, the highest mean score was for the students' recognition of the importance of English. Half the students, however, were afraid of asking teachers questions or stated they did not have enough confidence to speak in English. The major cause for this is the "face issue." Many Taiwanese students think asking questions in class will result in wasting time or being considered as foolish. "Face" plays a critical role for Taiwan students in the English classroom, but it is a paradoxical concept. In human interactions, we sometimes need to be involved with other participants, but we also need to maintain certain degree of independence from others (Scollon \& Scollon, 1995). Brown and Levinson (1987) give a universally valid model of "face" by saying that it is an individualistic and self-oriented image. However, the Chinese face is based on a core concept of honor and a more collective self, which means one is more concerned with membership in the groups than with the individual (Mao, 1994). Face relationships are prescribed for discourse among members or between members and outsiders. According to the Confucian tradition, a teacher is highly respected, and that view remains to the present, which is why students maintain a polite distance from their teachers.

Mao (1994) said that the Chinese, face (mianzi) is based on two principal arguments. First, for the Chinese, face emphasizes the harmony of individual conduct with the views and judgments of the community, not the accommodation of individual desires. Therefore, for the Chinese, face represents a public image rather than a self-image. When students speak English, they care how people view them. If they make mistakes, they are afraid of losing face. In this sense, it is safer not to speak in English. Second, for the Chinese, face does not contain the notion of a negative face. A Chinese individual desires to secure public acknowledgement of one's prestige or reputation. He or she is expected to seek the respect of community and identify one's desire to be liked and approved of by others, not to satisfy the desire for individual freedom. This helps to explain why students did not like to ask questions in the class, because they wanted to "save their face" when asking 
questions. They preferred to ask teachers privately or after classes, so they would feel safe asking questions. Thus it is fairly critical for native-speaking teachers who have interest or intention to work in oriental countries, especially in Taiwan, Mainland China, or Hong Kong, to be aware of the face issue.

Regarding research Question 3, a correlation test was used to examine the relationship between the time spent on English activities and students' attitudes. A significant and positive correlation shows that students who form positive attitudes toward English spend more time with English activities. This also means that the more the arts students like using English, the more time they spend on English-related activities. It forms to Weinburgh and Nunan's explanations of attitudes and students with positive attitude tend to spend more time developing language outside the classroom and it is a critical factor in the foreign language development.

\section{Pedagogical implications}

The results show that Taiwanese arts students are shy in their English classes. In Taiwanese society, tradition is highly valued, which is very different from the western societies. The crucial factor, face, plays a critical role and it is the synthesis of Chinese traditional culture, traditional concept of value and features of personality. Face is a hidden rule of Chinese ethnic groups, because "face" represents one's reputation in the society, and the reputation gained by achievements and praises during their life journey. It is important for native-speaking teachers or professors who teach Taiwanese students to be aware of the "face" issue and it will help them when designing and preparing courses. Otherwise, most native-speaking teachers or professors might experience "silent Chinese student" phenomenon (Dougherty \& Wall, 1991; Yang, 1993). That is when teachers or professors ask questions, there is a period of time of silence. If the teachers or professors call on a particular student, a timid answer will be heard (Hwang, Ang, \& Francesco, 2002) or that student will check his or her answer with classmates before answering the questions. Therefore, there are some suggestions for activities for teachers who are interested in teaching English in Taiwan.

For new students who meet the first time, it is necessary to do some icebreaker activities to be familiar with each other. For example (Ur \& Wright, 1995):

Find Someone Who: The students have five minutes to walk around the classroom and find at least one person who has the same birthday, the same number of brothers and sisters, the same... In the end, they show what they find to others.

Compare Yourself: In groups, students find something with which to compare themselves to each other. They can get to know each other and practice the use of comparatives. For example, you are taller than I am. John is older than Mary.

These tasks are suitable because students do not need to stand in front of the class. When walking around the classroom and talking to their classmates, it will reduce their nervousness and provide lower risk of face loss. In addition, as Chinese face deals with the view and judgment of the community, students feel safer to stay in groups in the beginning of the courses. Following that, individual conversation could be used.

According to conversational analysis, people talk to get attention. If they do not feel secure with the attention they get from an audience, their "face" might shake and they may lose the interest to talk. There are some activities that can be done to encourage students not only to listen to the teacher but also to their peers. For instance, when a student finishes talking about something, the teacher can ask others: What do you think about John's opinion? Do you agree? Mary, I could not hear what John just said, could you repeat it for me? These questions will encourage students to listen to others with their full attention. Without this encouragement, students may just sit there and wait until it is his or her turn to talk until class is over. If students are given the opportunity to make a short speech or a chance to share their opinions, an evaluation sheet can be designed to help students when they listen to others. In the evaluation sheet, they are asked to give comments or to score each other, and they have to explain and give their feedback to their classmates. 
Additionally, native-speaking teachers or professors think Taiwanese students diligent, well-motivated, and friendly to the teachers, but passive and unwilling to talk or give their comments to questions. Students in Taiwan care more about scores and exams. They like native-speaking teachers for their pronunciation and their cultural knowledge but they think the native speaking teachers are less helpful in teaching grammar and vocabulary. Therefore, it is important for native-speaking to pay more attention to linguistic knowledge not just on communication (Cortazzi \& Jin, 1998, 1999).

Holmes (1997) suggested the "Vote with Their Feet" technique. It may encourage students to participate in class. Holmes uses a debate in which students are asked to physically move to a certain area in the classroom to signify their vote on the issue in question. After the vote, there would be a debate between or among groups that voted differently from each other. This technique is normally used in conversation class but it can also be used in writing class. By asking students to write down their opinions or stand point of views, they have sufficient time to think and give their comments.

\section{Conclusion}

Being an arts student does not mean that students only practice their professional skills. An arts student still needs to attend and perform in international concerts, contests, performances, and exhibitions. The goal of this study was to determine how much time students spent with English-learning activities and to learn about their attitudes toward the English language. The results indicated that students actually spent sufficient time learning English and they recognized the importance and impact of English for their future. But although a picture can tell a thousand words, their efforts were limited because they had little confidence to speak English. Pedagogical implications are provided to help students overcome these problems and also provided as good references for teachers who wish to teach English to arts students in Taiwan.

\section{References}

Abdel-Rahman, A. (2009). Attitudes of Jordanian college students towards learning English as a foreign language. College Student Journal, 43(2), 682-294.

Abidin, J. M., Pour-Mohammadi, M., \& Alzwari, H. (2012). EFL students' attitudes towards learning English language: The case of Libyan secondary school students, Asian Social Science, 8(2), 119-134.

Al-Tamimi, A., \& Shuib, M. (2009). Motivation and attitudes towards learning English: A study of petroleum engineering undergraduates at Hadhramout University of Sciences and Technology. GEMA Online Journal of Language Studies, 9(2), 29-55.

Baker, C. (1988). Key issues in bilingualism and bilingual education. Clevedon, Avon: Multilingual Matters.

Bidin, S, Jusoff, K., Aziz, A. N., Salleh, M. M., \& Tajudin, T. (2009). Motivation and attitude in learning English among UiTM students in the northern region of Malaysia, English Language Teaching, 2(2), 16-20.

Brown, P. \& Levinson, S. (1987). Politeness. Cambridge: Cambridge University Press.

Chen C. Y., Chuo, C. C., \& Chou, P. P. (2003). An investigation of students' attitudes toward English instruction: A case study of Mei-Ho Institute of Technology. Journal of Mei-Ho Institute of Technology, 22(2), 303-324.

Cortazzi, M \& Jin, L. (1998). The culture the learner brings: a bridge or a barrier? Language Learning in Intercultural Perspective (pp.98-118). NY: Cambridge University Press.

Cortazzi, M. \& Jin, L. (1999). Cultural mirrors: Materials and methods in the EFL classroom. In Eli Kinkel (Eds), Culture in Second Language Teaching and Learning (pp.196-219). NY: Cambridge University Press.

Dougherty, T. W., \&Wall, J. A. (1991). Teaching in China during the age of reform. Journal of Management Education, 15(2), 232-243. http://dx.doi.org/10.1177/105256299101500207

Ellis, R. (1994). The Study of Second language Acquisition. Oxford University Press.

Gan, Z. D. (2009). Asian learners re-examined: An empirical study of language learning attitudes, strategies and motivation among Mainland Chinese and Hong Kong students. Journal of Multilingual and Multicultural Development, 30(1), 41-58. http://dx.doi.org/10.1080/01434630802307890 
Tseng, M.-C.

Gardner, R. C. \& Lambert, W. E. (1972). Attitudes and motivation in second language learning. Rowley, MA: Newbury House. In McKay, S. L., \& Hornberger, N. H. (2000). Sociolinguistics and language teaching. Cambridge University Press.

Garner, R. C. (1985). Social psychology and second language learning: The role of attitudes and motivation. London: Edward Arnold.

Holmes, J. (1997). Want participation? Have them "Vote with their Feet!". Journal of Management Education, 21(1), 117-120.

Holmes, J. (1998). An introduction to sociolinguistics. Addison Wesley Longman, Ltd. http://dx.doi.org/10.1177/105256299702100110

Hwang, A., Ang, S., \& Francesco, A. M. (2002). The silent Chinese: The influence of face and Kiasuism on student feedback-seeking behaviors. Journal of Management Education, 26(1), 70-98. http://dx.doi.org/10.1177/105256290202600106

Mao, R. L. (1994) Beyond politeness theory: 'Face' revisited and renewed. Journal of Pragmatics, 21, 451-486. http://dx.doi.org/10.1016/0378-2166(94)90025-6

Noursi, A. O. (2013). Attitude towards learning English" the case of the UAE technological high school, Educational Research, 4(1), 21-30.

Nunan, D. (1991). Language Teaching Methodology. London: Prentice Hall.

Oliver, J. S, \& Simpson, R. D. (1988). Influences of attitude toward science, achievement motivation, and science self-concept on achievement in science: A longitudinal study. Science Education, 72(2), 143-155. http://dx.doi.org/10.1002/sce.3730720204

Pickard, N. (1996). Out-of-class language learning strategies. ELT journal, 50(2), 150-159. http://dx.doi.org/10.1093/elt/50.2.150

Pill, T. (2001) Adult learners' perceptions of out-of-class access to English. Unpublished MA Thesis, University of Hong Kong.

Sayadian, S. \& Lashkarian, A. (2010). Investigating attitudes and motivation Iranian university learners toward English as a foreign language. Contemporary Issues in Education Research, 3(1), 137-148.

Schibeci, R. A., \& Riley, J. P. (1986). Influence of students' background and perceptions on science attitudes and achievement. Journal of Research in Science Teaching, 23(3), 17-187. http://dx.doi.org/10.1002/tea.3660230302

Scollon, R. \& Scollon, S.W. (1995). Intercultural communication: A discourse approach. Blackwell Publishers.

Suad Ahmen, Al-Bustan., \& Lamees, 1-Bustan. (2009). Investigating students' attitudes and preferences towards learning English at Kuwait university. College Student Journal, 43(2), 454-463.

Sung, K. Y., \& Tsai, H. M. (2014). Motivation and learner variables: Group differences in college foreign language learners' motivation. International Journal of Research Studies in Language Learning, 3(2), 43-54. http://dx.doi.org/10.5861/ijrsll.2013.561

Tseng, M. C. (2009). A needs analysis of English curriculum design: A case study for medical students. Paper presented at the Conference themed as "A talk between humanity and medicine", Chang Gung University, Taiwan.

Tsuda, S. (2003). Attitudes toward English language learning in higher education in Japan (2): Raising awareness of the notion of global English. Intercultural Communication Studies, 7(3), 61-75.

Ur, P., \& Wright, A. (1995). Five-minute activities: A resource book of short activities. Cambridge University Press.

Weinburgh, M. H. (1994). Achievement, grade level, and gender as predictors of student attitudes toward science. Paper presented at the Distinguished Paper Session of the annual meeting of the American Association of Educational Research, New Orleans.

Weinburgh, M. H. (2000). Gender, Ethnicity, and Grade Level as Predictors of Middle School Students' Attitudes toward Science. Retrieved Nov. 09, 2014 from http://files.eric.ed.gov/fulltext/ED442662.pdf

Yang, K. S. (1993). Chinese social orientation: An integrative analysis. In L. Y. Cheng, F.M.C. Cheung, \&C. N. Chen (Eds.), Psychotherapy for the Chinese: Selected papers from the first international conference (pp. 19-56). Hong Kong: The Chinese University of Hong Kong. 
An investigation of Taiwanese arts students' English learning attitudes

Yap, S. L. (1998). Out-of-class use of English by secondary school students in a Hong Kong Anglo-Chinese school, Doctoral dissertation, University of Hong Kong.

Yoshikawa, H. (2000). The attitude toward and recognition of English in Korea with reference to English in Japan. Intercultural Communication Studies, 5(1), 23-28.

Zafarghandi, M. A., \& Jodai, H. (2012). Attitudes toward English and English learning at an Iranian military university: A preliminary survey. International Journal of Social Sciences and Education, 2(1), 102-123. 


\section{Taiwanese Arts Students' English Learning Attitudes}

Instructions: The questionnaire is designed to investigate the current situations of English education for arts students in Taiwan. It should require about 10 to 15 minutes of your time to complete the survey. Usually it is best to respond it with your first impression without giving any single question much thought. Your answers will remain confidential and only researchers of this study will have access to your responses. Your participation will certainly benefit the revision and adjustment of English education in possible future. Thank you for your precious time!

\section{Part I - Basic Information and Relevant English Activities}

1. Gender: $\square$ Male $\square$ Female

2. Age:

3. Which year are you studying? Department:

4. Until now, did you have any experiences of living abroad?

$\square$ No

$\square$ Yes How many years did you stay there?

Location?

How old were you?

Why?

5. How many hours a week do you read English books? About hours

6. How many hours a week do you watch English movies? About hours

7. How many hours a week do you browse English websites? About hours

8. How many hours a week do you listen to English radio stations? About hours

9. How many hours a week to chat in English via Yahoo Messenger, or MSN Messenger or Skype?

About hours

10. How many hours a week do you speak in English? About hours

11. Your highest English proficiency test

$\square$ N/A
$\square$ GEPT_Level___ __ score
$\square$ TOEFL_scores
$\square$ TOEIC__ score
$\square$ Others__

12. What is your goal for your English proficiency test?

$\square$ GEPT___Level___ score $\_$score
$\square$ TOEFL_score
$\square$ TOEIC__
$\square$ Others

13. How often do you have the opportunities to go abroad now?

What are the purposes? 
Part II English Learning Attitudes (please put a tick on the line)

1. I feel confident to speak in English.

No confident
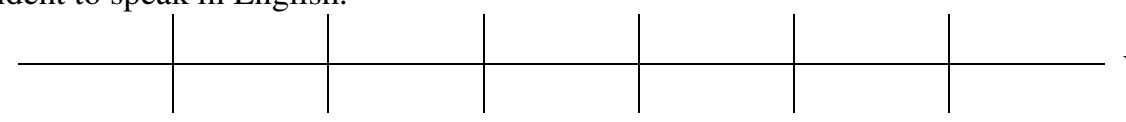

Very Confident

2. I feel so happy to attend English classes.

Very unhappy

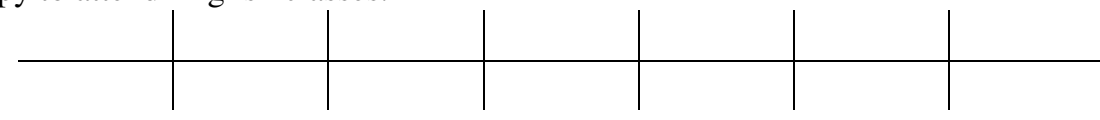

Very happy

3. I think it is important to learn English well.

Not important
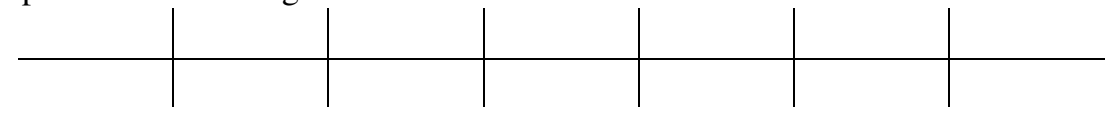

Very important

4. I think English will help me a lot for my future.

Not helpful

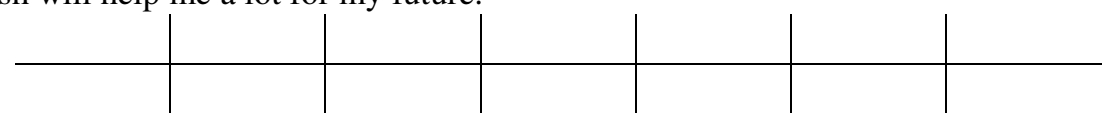

Very Helpful

5. I believe I have the ability to learn English well.

No ability

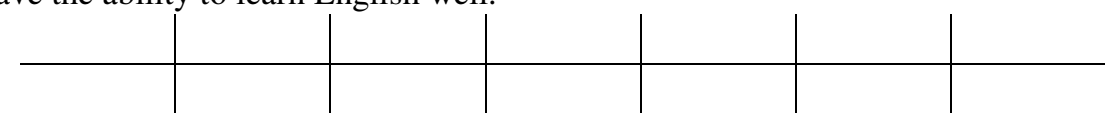

Very Capable

6. I can absorb foreign culture in the English class.

Absorb

nothing
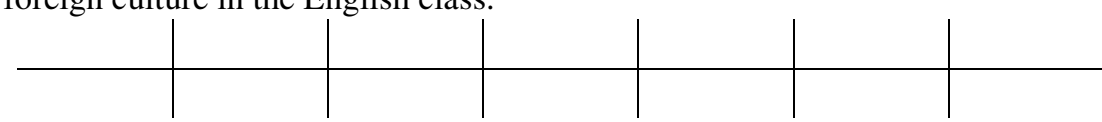

Absorb a lot

7. I can understand most of the content of English textbook.

Don't

understand
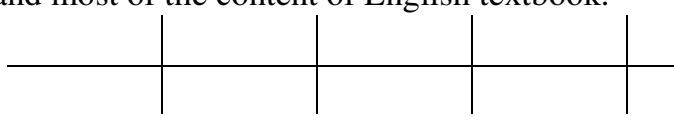

Understand a lot

8. If I do not understand anything, I will ask teachers.

Won't ask

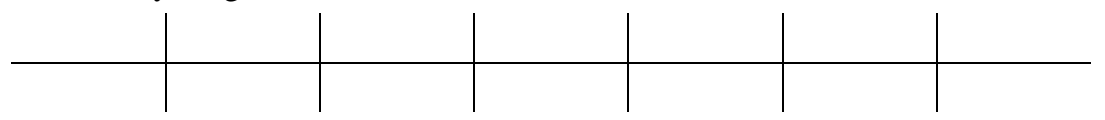

Very actively

9. After graduation, English will be useful in a lot of places.

Not useful

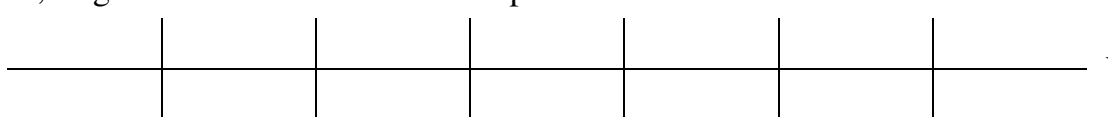

Very useful

10. I like to learn anything about English.

Not at all

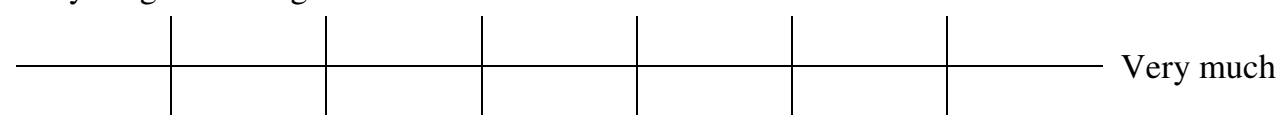


11. I hope I can take more English classes.

Not at all

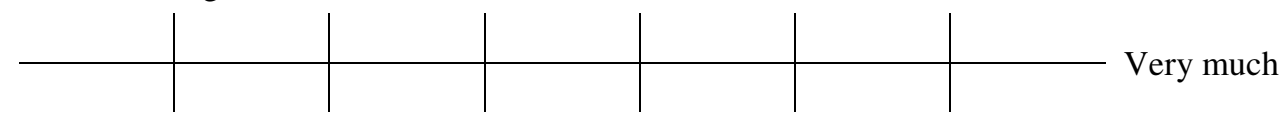

12. I believe if I study hard, I can learn English well.

Not at all

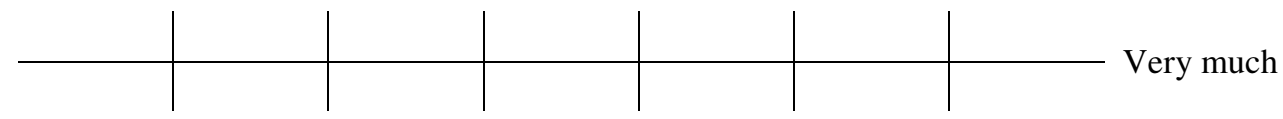

13. I am positive in learning English.

Negative

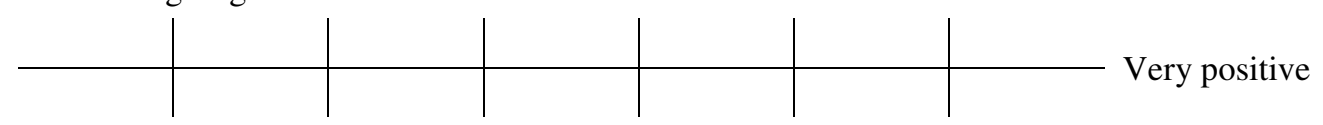

14. I would like to spend more time studying English.

Not at all

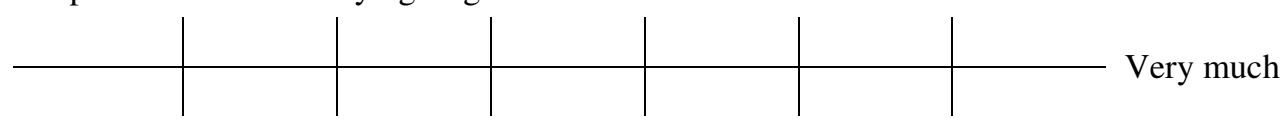

15. If I do not know anything in the class, I will immediately raise my hand and ask teacher.

Not at all

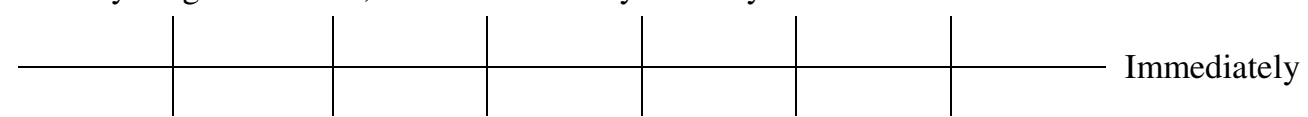

The End of the Questionnaire!

Thank you! 